Vol. 1 No. 3 November 2021, e-ISSN : 2797-0140 | p-ISSN : 2797-0590

\title{
PENGEMBANGAN SOFTWARE BERHITUNG \\ DALAM PEMBELAJARAN MATEMATIKA \\ PADA MATERI BANGUN DATAR DAN BANGUN RUANG
}

\author{
LIA SEPTIANI \\ Pascasarjana PMIPA, Universitas Indraprasta PGRI, Jakarta \\ Email : liaseptiani222@gmail.com
}

\begin{abstract}
ABSTRAK
Perkembangan dunia teknologi pada saat ini memberikan pengaruh serta dampak yang besar terhadap perkembangan teknologi pendidikan khususnya pada pemprogaman mengembangan teknologi pada bidang Matematika. Melihat perkembangan dunia pendidikan, tentunya menuntut para pendidik dapat menggunakan teknologi yang dapat digunakan sebagai media pembelajaran ialah teknologi komputer.. Media pembelajaran sangat dibutuhkan oleh para pendidik untuk meningkatkan minat belajar peserta didik, mempermudah proes pembelajaran dan memberikan praktik langsung kepada peserta didik. Alat bantu matematika secara nyata adalah kalkulator yang hanya menghitung bagian dasar dari hitungan. Penenlitian ini bertujuan untuk mengembangkan sotfware berhitung dalam pembelajaran matematika khususnya mengembangan kalkulator. Penelitian dan Pengembangan (research and development) is process used to the develop and validate educational products. Penelitian dan pengembangan yang digunakan dalam mengembangkan media pembelajaran matematika menggunakan pendekatan research and development dengan mengembangkan media pembelajaran dapat digunakan model desain system pembelajaran, ADDIE (Analysis Design Develop Implement Evaluate). Hasil ujicoba ahli media dengan nilai 3.07, yang berarti memiliki kriteria baik, hasil ujicoba ahli materi dengan nilai 3.40, yang berarti memiliki kriteria baik, hasil ujicoba ahli desain pembelajaran dengan nilai 3.40 yang berarti memiliki kriteria baik. Sedangkan pada ujicoba one to one dengan nilai 3.33, yang berarti memiliki kriteria baik, hasil ujicoba small group dengan nilai 3.31, yang berarti memiliki kriteria baik dan hasil uji coba field test 3.18. sehingga rata-rata keseluruhan dari evalusi para ahli dan ujicoba peserta didik memiliki persentase $82.04 \%$, yang berarti software berhitung dalam pembelajaran matematika yang diberi nama kalkulator bangun datar dan bangun ruang dapat dikategorikan baik.
\end{abstract}

Kata Kunci: Pembelajaran Matematika, Software Berhitung, Pengembangan

\section{ABSTRACT}

The development of the world of technology at this time has a great influence and impact on the development of educational technology, especially in programming to develop technology in the field of Mathematics. Seeing the development of the world of education, of course, requires educators to be able to use technology that can be used as a learning medium, namely computer technology. Learning media is needed by educators to increase students' interest in learning, simplify the learning process and provide direct practice to students. A real math aid is a calculator that only calculates the basic part of the calculation. This research aims to develop counting software in learning mathematics, especially developing calculators. Research and development is a process used to develop and validate educational products. Research and development used in developing mathematics learning media using a research and development approach by developing learning media can be used as a learning system design model, ADDIE (Analysis Design Develop Implement Evaluate). The results of the media expert test with a value of 3.07, which means it has good criteria, the results of the material expert test with a value of 3.40, which means it has good criteria, the results of the learning design expert test with a value of 3.40 which means it has good criteria. Meanwhile, in the one to one trial with a value of 3.33, which means that it has good criteria, the results of the small group trial with a value of 3.31, which means it has good criteria and the results of the field test test are 3.18. so that the overall average of the expert evaluations and student trials has a percentage of $82.04 \%$, 
which means that the counting software in mathematics learning which is named the flat and geometric calculator can be categorized as good.

Keywords: Mathematics Learning, Computing Software, Development

\section{PENDAHULUAN}

Dewasa ini perkembangan teknologi semakin pesat, sehingga apapun saat ini berkaitan dengan teknologi. Sejalan dengan perkembangan yang sangat pesat dari teknologi, kini dunia pendidikan pun tidak kalah berkembang tentunya salah satunya ditunjang dengan teknologi yang dijadikan sebagai salah satu media pembelajaran. Melihat perkembangan dunia pendidikan, tentunya menuntut para pendidik dapat menggunakan teknologi yang dapat digunakan sebagai media pembelajaran ialah teknologi komputer.

Kebanyakan diantara siswa/i mempunyai pengalaman pahit sewaktu mempelajari matermatika dibangku Sekolah Dasar dan lanjutan. Kenyataan ini kemudian berkelanjutan menjadi suatu kebencian terhadap apa saja yang ada hubungannya dengan matematika. Bahwasanya matematika tidak popular di masyarakat antara lain ditunjukan oleh sedikitnya minat generasi muda Indonesia untuk mempelajarinya sebagai keahliannya. Banyak orang yang menyatakan bahwa matematika sebagai pelajaran yang sukar. Dalam proses pembelajaran perlu adanya pembuktian hasil untuk memupuk kepercayaan diri pada hasil yang sudah didapatkan, seperti membuktikannya dengan kalkulator, untuk menunjang kepercayaan diri saat belajar mandiri di rumah.

Dalam hal tersebut media pembelajaran sangat dibutuhkan oleh para pendidik untuk meningkatkan minat belajar peserta didik, mempermudah proes pembelajaran dan memberikan praktik langsung kepada peserta didik. Dengan demikian para pendidik wajib untuk mengembangkan potensi dalam dirinya untuk menguasai berbagai media pembelajaran yang cocok untuk berbagai materi pembelajaran Matematika. Menurut Hamzah dan Kuadrat (2009: 108), matematika merupakan alat pikir, berkomunikasi, alat untuk memecahkan berbagai persoalan praktis, yang unsur-unsurnya logika dan intuisi, analisis dan kontruksi, generalitas dan individualitas, dan mempunyai cabang-cabang antara lain aritmatika, aljabar, geometri, dan analisis. Sedangkan menurut Ariani dan Haryanto (2010:33), setiap guru wajib membuat media pembelajaran dan menayangkannya (mempergunakan) dalam pembelajaran. Dalam hal ini peneliti pengembangkan kalkulator dalam bentuk software untuk untuk menghitung bangun datar dan bangun ruang.

\section{METODE PENELITIAN}

Penelitian ini dilakukan di Bekasi, tepatnya pada SD Islam Teratai Putih Global Kota Bekasi, SD Negeri Mangun Jaya 03 Kab. Bekasi dan SMP Negeri 3 Tambun Selatan, dengan memfokuskan penelitian pada siswa yang sedang belajar materi bangun datar dan bangun ruang yaitu siswa kelas V, VI dan VII. Pada penelitiaan ini menggunakan metode Penelitian dan Pengembangan (research and development). Mengembangkan media pembelajaran dapat digunakan model desain system pembelajaran, ADDIE (Analysis Design Develop Implement Evaluate), yakni dengan langkah (1) Analysis (analisa) yaitu melakukan needs assessment (analisis kebutuhan), mengidentifikasi masalah (kebutuhan), dan melakukan analisis tugas (task analysis), (2) Design (perancangan) yaitu merumuskan tujuan pembelajaran yang SMAR (spesifik, measurable, applicable, dan realistic), (3) Development (pengembangan) yaitu kegiatan membuat program software berhitung dari rancangan rumus pada tahap sebelumnya, dalam tahap ini mewelati pra produki, produksi, dan pasca produksi. (4) Implementation (Implementasi) yaitu langkah nyata untuk menerapkan sistem pembelajaran, pada tahap ini semua yang telah dikembangkan diinstal atau disetting sesuai dengan peran atau fungsinya agar bisa diimplementasikan, (5) Evaluation (evaluasi/ umpan balik) yaitu evaluasi yang terjadi pada setiap empat tahap di atas itu dinamakan evaluasi formatif yang bertujuan untuk kebutuhan revisi. Evaluasi merupakan langkah terakhir dari model desain sistem pembelajaran ADDIE. 
Evaluasi merupakan sebuah proses penting yang dilakukan untuk memberikan nilai pada program pembelajaran.

\section{HASIL DAN PEMBAHASAN}

Hasil pengembangan penelitian ini membahas tentang analisis dan kevalidan software yang dibuat. Pengembangan software ini berupa program yang diaplikasikan pada PC atau Laptop, dengan menggunakan langkah-langkah pengembangan dengan model ADDIE (Analysis Design Develop Implement Evaluate).

\section{Hasil Analysis (Analisis)}

Pada tahap awal, sebelum dilakukan pengembangan media pembelajaran, penelitian diawali dengan survei pendahuluan terkait dengan penggunaan media pembelajaran matematika pada materi bangun datar dan bangun ruang. Hasil studi pendahuluan di dapat bahwa dalam pembelajaran matematika pada materi bangun datar dan bangun ruang yang selama ini dilakukan oleh pendidik tidak pernah menggunakan media khususnya kalkulator bangun datar dan bangun ruang.

\section{Analisis Kebutuhan}

Berdasarkan hasil studi pendahuluan, maka terdapat hal yang menjadi kebutuhan yang sangat perlu untuk di tingkatkan yaitu mengenai media pembelajaran matematika guru dalam mengajar khususnya pada materi bangun datar dan bangun ruang. Wujud konkret dari hal tersebut adalah penguasaan terhadap penggunaan media pembelajaran matematika dengan materi bangun datar dan bangun ruang. Berdasarkan kebutuhan tersebut maka disusunlah sebuah media yang dapat menampung kebutuhan peserta didik tersebut.

\section{Analisis Materi}

Kebutuhan awal untuk media tersebut adalah menganalisis rumus bangun datar dan bangun ruang. Penulis menganalisis rumus matematika untuk semua bangun datar dan bangun ruang, misalnya bangun ruang balok maka penulis membuat rumus untuk mencari volume, panjang, lebar serta tinggi jika disandingkan dengan volume dan rumus untuk mencari luas permukaan, panjang, lebar dan tinggi jika disandingkan dengan luas permukaan. Dengan begitu untuk bangun balok membutuhkan 8 rumus. Begitupun dengan bangun yang lainnya sesuai dengan kebutuhannya masing-masing.

\section{Analisis Sasaran}

Materi bangun datar dan bangun ruang berada pada tingkat SD dan SMP, jadi sasaran pengguna produk ini adalah pendidik SD dan SMP. Tetapi penenliti memilih kelas V, VI dan VII sebagai sampel.

\section{Hasil Design (Perancangan)}

Pada tahap mendesain media tersebut, peneliti menyesuaikan pada analisis yang sudah dilakukan sebelumnya. Berikut desain media yang akan dikembangankan :

\section{a. Nama Media dan Karakteristik Media}

Nama media dari pengembangan ini adalah "Kalkulator Bangun Datar dan Bangun Ruang" dengan judul "Pengembangan Software Berhitung Dalam Pembelajaran Matematika". Materi yang disajikan mengenai bangun datar dan bangun ruang. Kalkulator bangun datar dan bangun ruang dalam pembelajaran matematika ini disajikan sebagai media pendidik dalam perhitungan bangun datar dan bangun ruang.

\section{b. Kebutuhan Sistem}

Kalkulator bangun datar dan bangun ruang ini dapat digunakan dan dijalankan dengan seperangkat komputer/laptop. Jika ingin mengoperasikan program ini di komputer maka harus dengan spesifikasi sebagai berikut:

1. Sistem operasi minimal Windows XP SP1/SP2 (dianjurkan Windows Vista atau Windows7) maupun Macintosh/Mac OS. 
2. Prosesor Intel Pentium IV ke atas atau sejenisnya (dianjurkan Dual Core atau Core 2 Duo).

3. Memori/RAM minimal $128 \mathrm{MB}$ (dianjurkan $256 \mathrm{ke}$ atas).

4. Jenis layar monitor SVGA resolusi 1024 x 768 pixel dengan 16 bit atau 24 bit warna.

\section{c. Prosedur Pemanfaatan}

Kalkulator dalam pembelajaran matematika ini disajikan sebagai media berhitung dalam proses pembelajaran. Prosedur pemanfaatan kalkulator bangun datar dan bangun ruang ini sangat sederhana, sama seperti menggunakan kalkulator hitung biasa. Hanya saja dalam memulai perhitungan harus memilih menu sesuai dengan kebutuhan bangun ruang atau bangun datar yang ingin dihitung.

\section{Hasil Development (Pengembangan)}

Pada tahap pengembangan ini, penulis mengembangan software dengan bantuan perangkat keras berupa komputer dan perangkat lunas yang digunakan yaitu Miscrosoft Visual Basic 6.0. Penulis mengacu pada materi bangun datar dan bangun ruang antara lain persegi, persegi panjang, trapesium, lingkaran, layang-lanyang, belah ketupat, kubus, balok, bola, kerucut, limas segiempat, limas segilima, prisma segitiga dan tabung.

Tahap awal program, peneliti membuat tampilan awal software berhitung, menggunakan microsoft publisher pada tahapan awalnya kemudian di ubah menjadi JPG dan dikonfersikan ke dalam microsoft visual basic. Kedua pembuatan desain tampilan, dalam pembuatan desain tampilan, penyesuaian warna font, ukuran font, size, dan warna background. Ketiga tahap pembuatan tampilan isi, penyesuaian tombol klik dan gambar sesuai dengan rumus yang akan di input. Rumus yang digunakan sesuai dengan pra produksi namun disesuaikan dengan rumus microsoft visual basic.

Pada tahap ini peneliti sangat memperhatikan hasil dari media tersebut sesuai atau tidak dengan hitungan matematika. Dalam tahap ini kesesuaian rumus matematika yang disesuaikan dengan rumus microsoft visual basic diperlukan ketetilian dalam penginputan. Selanjutkan perapihan program dengan penyesuaian tata letak dan sebagainya.

\section{Hasil Implementation (Implementasi)}

Pada tahap implementasi ini, media tersebut siap didistribusikan dan diimplementasikan kepada kelompok sasaran yaitu pada ahli media, ahli materi, ahli desain pembelajaran dan siswa dengan tiga tahap (one to one, small group dan field test). Pada siswa tahap pertama (one to one) yaitu melibatkan satu peserta didik sekolah Dasar Islam Teratai Putih, satu peserta didika Sekolah Dasar Negeri Mangunjaya 03 dan peserta didik Sekolah Menengah Pertama Negeri 3 Tambun Selatan. Pada sisswa tahap kedua (small group) yaitu melibatkan dua peserta dari tiap sekolah dasar dan satu orang dari sekolah menengah pertama, lalu tahap terakhir (field test) yaitu melibatkan empat Pada tahap ini tiap sasaran menerapkan sekaligus mencoba media tersebut.

\section{Hasil Evaluation (Evaluasi/Umpan Balik)}

Hasil dari tahap ini terdapat enam hasil dari penilaian sasaran, yaitu hasil ujicoba ahli media, hasil ujicoba ahli materi, hasil ujicoba alhi desain pembelajaran, hasil ujicoba one to one, hasil ujicoba small group dan hasil ujicoba field test untuk menilai kelayakan software berhitung tersebut. Setelah penelitian dilakukan kepada ahli media dengan hasil perolehan 3,07 dengan merevisi tema tampilan yang kurang menarik dan perlu disesuiakan dengan kesukaan anak-anak, selanjutnya kepada ahli materi dengan hasil perolehan 3,40 dengan tanggapan hasil perhitungan rumus manual dengan kalkulator sesuai dan perlu direvisi tampilanyang kurang menarik dan perlu dikembangkan pada materi trigonometri atau geometri dan pada ahli desain pembelajaran mendapatkan hasil 3,40 dengan tanggapan dapat memudahkan guru mendapatkan hasil secara cepat dan merevisi bentuk tulisan dan perlu keindahan dalam media tersebut. 
Selain itu analisis data respon siswa juga dibutuhkan untuk menentukan hasil kelayakan software berhitung tersebutdiujicobakan pula kepada siswa yang terbagi menjadi tiga tahap, yaitu (1) Kepada tiga orang siswa pada uji coba one to one memperoleh hasil 3,33 dengan respon membuktikan hasil hitungan yang sduah didapatkan sebeumnya, (2) Kepada 5 orang siswa pada uji coba small group memperoleh hasil 3,31 dengan respon yang berbeda-beda ada yang membuktikan, mempermudah pengerjaan tugas dan lainya, serta (3) Kepada 15 orang pada field test memperoleh hasil 3,18 dengan respon yang semakin beragam.

\section{Kelebihan Media Kalkulator Bangun Datar Dan Bangun Ruang}

Kelebihan media kalkuator bangun datar dan bangun ruang pembelajaran Matematika ini sebagai media pembelajaran adalah menyajikan materi yang dikemas dalam perhitungan dengan menggunakan bahasa yang mudah dimengerti. Selain itu dapat meningkatkan kualitas belajar peserta didik dan ilustrasi yang disesuaikan dengan materi dan warna serta tulisan yang sesuai untuk mendukung pesan.

Kemudahan mengoperasikan program dengan melalui peralatan pendukung seperti komputer atau laptop. Program kalkulator bangun datar dan bangun ruang ini disesuaikan dengan karakteristik dari sasaran yaitu peserta didik kelas V, VI dan VII. Kalkulator bangun datar dan bangun ruang ini juga dapat dimanfaatkan dalam pembelajaran di kelas sebagai media pembelajaran dengan disertai petunjuk penggunaan program.

Dari seluruh kegiatan pengembangan yang telah dilakukan, berikut persentase hasil rekapitulasi pada hasil validasi kelayakan software berhitung dalam pembelajaran matematika.

Tabel 1. Persentase Hasil Uji Coba Keseluruhan

\begin{tabular}{|c|c|c|c|c|c|}
\hline No. & Uji Coba & $\begin{array}{c}\text { Rerata } \\
\text { Skor }\end{array}$ & $\begin{array}{c}\sum \text { Rerata } \\
\text { Skor }\end{array}$ & $\begin{array}{c}\sum \text { Skor } \\
\text { Max }\end{array}$ & $\begin{array}{c}\text { Persentase } \\
(\%)\end{array}$ \\
\hline 1. & Ahli Media & 3.07 & 46 & 60 & 76.67 \\
\hline 2. & Ahli Materi & 3.40 & 51 & 60 & 85 \\
\hline 3. & Ahli Desain Pembelajaran & 3.40 & 51 & 60 & 85 \\
\hline 4. & One to one & 3.33 & 150 & 180 & 83.33 \\
\hline 5. & Small Group & 3.31 & 248 & 300 & 82.67 \\
\hline 6. & Field Test & 3.18 & 716 & 900 & 79.56 \\
\hline \multicolumn{4}{|c|}{ Persentase Rata-Rata } \\
\hline
\end{tabular}

Berdasarkan data keseluruahan pada Tabel 1, dengan hasil persentase keseluruhan memperoleh nilai $82.04 \%$ maka dapat dianalisis software berhitung dalam pembelajaran matematika yang diberi kalkulator bangun datar dan bangun ruang dapat dikategorikan baik dan layak. Sehingga dari keseluruhan proses dapat disimpulkan bahwa produk pengembangan pada penelitian ini telah memenuhi kriteria kelayakan program.

Pada penelitian tersebut peneliti menemukan penelitian sebelumnya yaitu Efektifitas Mathmagic dalam Peningkatan Hasil Belajar Matematika oleh Chatarina Febriyanti (2016) yang menghasilkan Metode perhitungan mathmagic efektif dan efisien dalam materi perkalian, selain itu penelitian yang berjudul Membangun Aplikasi Alarm Menggunakan Visual Basic 6.0 oleh Andi Dwi Riyanto yang menghasilkan produk alarm yang dapat digunakan di PC atau Laptop. Penelitian yang dilakukan Chatarina Febriyanti memberikan dan menguji metode perhitungan demi mengefektifkan belajar Matematika, sedangkan penelitian yang dilakukan Andi Dwi Riyanto (2008) membangun aplikasi untuk PC atau Laptop, dari dua penelitian tersebut peneliti mengembangkan dalam bentuk software berupa kalkulator yang bertujuan untuk membuktikan hasil perhitungan yang dapat dioperasikan di PC atau Laptop. Peneliti menggabungkan dua ide tersebut dengan dikembangkan dalam bentuk perhitungan pada bangun datar dan bangun ruang yang diaplikasikan pada PC atau Laptop. 


\section{KESIMPULAN}

Dari analisis diatas dapat dikatakan bahwa software berhitung dalam pembelajaran matematika pada materi bangun datar dan bangun ruang memiliki hasil perhitungan yang sesuai sehingga diterima oleh para ahli dan pengguna. Berdasarkan hasil presentasi penilaian pada media tersebut memiliki kriteria baik dengan persentase $82,04 \%$. Sebagian responden merasa lebih mudah dalam mengimplenetasikannya dengan menu dan tampilan yang mudah untuk dipahami.

Program ini dibuat sebagai media pembelajaan untuk membantu pendidik dalam pemecahan masalah matematika pada materi bangun datar dan bangun ruang. Dalam hal ini penggunaan media dalam aktivitas pembelajaran dapat memfasilitasi tercapainya kompetensi atau tujuan pembelajaran seperti yang diharapkan pendidik dan peserta didik. Media pembelajaran yang dikembangkan diharapkan dapat meningkatkan meovasi dan memudahkan siswa dalam belajar dan dengan adanya media ini siswa mampu secara mandiri mengreksi hasil perhitungannya. Media pembelajaran yang dikembangkan masih belum sempurna oleh karena itu perlu dikakukan perbaikan yang berpedoman pada prosedur pengembangan untuk pengembangan kedepannya.

\section{DAFTAR PUSTAKA}

Abdurrahman, Mulyono. (2003). Pendidikan bagi Anak Berkesulitan Belajar. Jakarta : PT. Rineka Cipta.

Ariani, Niken dan Haryanto, Dany. (2010). Pembelajaran Multimedia di Sekolah (Pedoman Penuh Inspriratif Konstriktif dan Prospektif). Jakarta : PT. Prestasi Pustakaraya

Gatot, Ryco. (2013). Pengembangan Media Pembelajaran Games Perkalian Untuk Menstimulasi Kemampuan Peserta Didik SD. Skirpsi : Universitas Negeri Jakarta.

Hamzah, B. Uno dan Kuadrat. (2009). Mengelola Kecerdasan Dalam Pembelajaran : Suatu Konsep Pembelajaran Berbasis Kecerdasan. Jakarta : Bumi Aksara.

Imaniawan, Fabriyan Fandi Dwi., Riyanto, Andi Dwi. (2015). Perancangan Sistem Informasi Akademik Berbasis Web pada Akademi Pertanian HKTI Banyumas. Jurnal Telematika, Vol 8 No. 1

Irawan, Ari., Febriyanti, Chatarina Efektifitas. (2016). Mathmagic dalam Peningkatan Hasil Belajar Matematika. Formatif: Jurnal Ilmiah Pendidikan MIPA, Vol 6, No 1

Liberna, Hawa dan Wiratomo, Yogi. (2014). Metode Pembelajaran Matematika. Jakarta : Mitra Abadi.

M, Ali. (2013). Metode Penelitian. 2013. Jakarta : PT. Rineka Cipta.

Musfiqon. (2012). Pengembangan Media dan Sumber Pembelajaran. Jakarta : Prestasi Pustaka Sommerville, Ian. 2003. Software Engineering. Jakarta :Erlangga

Sugiarta. (2007). Model Pengembangan. Jakarta : Erlangga

Sugiono. (2011). Metode Penelitian Kuantitatif, Kualitatif dan R \& D. Bandung : Alfabeta

Supardi, U.S. (2013). Hasil Belajar Matematika Siswa Ditinjau dari Interaksi Tes Formatif Uraian dan Kecerdasan Emosional. Jurnal Formatif, Vol 3(2) : 78-96. Keluarga Alumni UniversitasIndraprasta PGRI. 